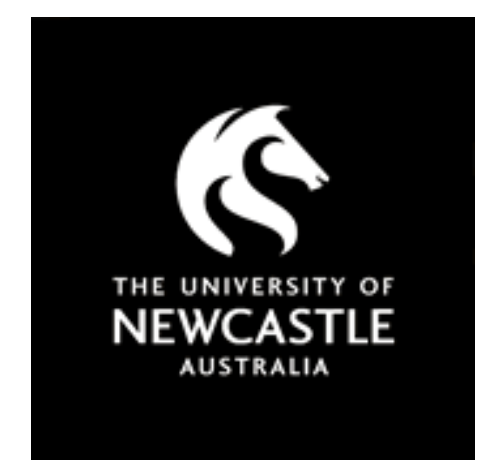

NOVA

University of Newcastle Research Online

nova.newcastle.edu.au

Gore, Jennifer; Bowe, Julie. "Interrupting attrition?: re-shaping the transition from preservice to inservice teaching through Quality Teaching Rounds",

Published in the International Journal of Educational Research Vol. 73, p. 77-88. (2015)

Available from: $\underline{\text { http://dx.doi.org/10.1016/j.ijer.2015.05.006 }}$

(C) 2015. This manuscript version is made available under the CC-BY-NC-ND 4.0 license http://creativecommons.org/licenses/by-nc-nd/4.0/

Accessed from: $\underline{\text { http://hdl.handle.net/1959.13/1336628 }}$ 


\title{
Interrupting attrition? Re-shaping the transition from preservice to inservice teaching through Quality Teaching Rounds
}

\author{
Jennifer M. Gore*, Julie M. Bowe
}

School of Education, The University of Newcastle, Australia

\begin{abstract}
The potential of rounds for impacting on teacher development is significant. However, rounds are conceptualised in multiple ways and there is little evidence of how they work, particularly for beginning teachers. This article examines how our approach, "Quality Teaching Rounds", shapes the transition from preservice to inservice teaching. We analyse the discursive, subjectification, and lived effects of this form of rounds, drawing on interviews with 39 teachers in studies conducted between 2009 and 2014. Our analysis shows positive effects for these beginning teachers, including greater confidence, stronger professional relationships, and a clearer vision of their goals. We argue that the pedagogical framework and specific processes of our approach are critical to ensuring its positive effects and potentially interrupting attrition.
\end{abstract}

Keywords:

Teacher development

Rounds

Attrition

Beginning teachers

Early career teachers

* Corresponding author at: The University of Newcastle, School of Education, University Drive, Hunter Building HA80, Callaghan NSW 2308, Australia. Tel.: +61 24921 6709; fax: +61 249217887.

Email address: jenny.gore@newcastle.edu.au

Note. This is a post-print version of the manuscript which was submitted to the International Journal of Educational Research and accepted for publication on 8 May 2015. To access the article online, please go to: http://dx.doi.org/10.1016/j.ijer.2015.05.006

(C) 2015, Jennifer M. Gore and Julie M. Bowe. This manuscript version is made available under the CC-BY-NC-ND 4.0 license. http://creativecommons.org/licenses/by-nc-nd/4.0/ 


\section{Introduction}

The conduct of rounds has gained significant momentum as an approach to teacher development in both preservice and inservice contexts. Advocated in education since 20071, rounds have subsequently taken several forms, as this special issue attests. Best known among these are "instructional rounds" (Elmore, 2007) and "teacher rounds" (Del Prete, 2013), the former oriented at school improvement and the latter focused on teacher education. With the exception of a few recent conference papers (Bowe, Gore, \& Elsworth, 2010; Gore, Bowe, Clement, Ellis, \& Miller, 2012; Roegman $\&$ Riehl, 2014), literature on rounds has been largely descriptive and celebratory. Our aim in this article is to contribute both to the conceptualisation of rounds and to the currently slim body of evidence addressing their effects.

Conceptually, rounds appeal as an approach to teacher development given their alignment with contemporary views about effective professional development. They focus on detailed description and analysis of practice; take account of local contexts; and use collaborative processes to build a collective vision of a way forward (Hawley \& Valli, 1999; Imants \& van Veen, 2010; Newmann, King, \& Youngs, 2000).

Given their lineage in medical education, rounds also have the appearance of greater objectivity than other approaches to teacher development. While seen by some commentators as increasing rigor and credibility, it is precisely this feature that also elicits critique on the basis that learning to teach is incommensurable with the "clinical" diagnostic approaches that characterise medical education. Further conceptual and empirical analyses will help build deeper understanding of the potential of rounds, in their diverse forms.

In this article, we discuss "Quality Teaching Rounds", our own approach to supporting teacher development (Bowe $\&$ Gore, under review), and identify some of its effects through a series of research studies we have conducted since 2007 (Gore, 2014). Drawing on interview data from three implementation studies, we examine how teachers in the first three years of their careers experience Quality Teaching Rounds.

Constructing high impact approaches to teacher development remains a challenge affecting education systems in many nations. Our focus on the effects of Quality Teaching Rounds for teachers at the beginning of their careers is designed to respond to global concerns about high levels of attrition and burn out among early career teachers (e.g., Clandinin, Downey, \& Schaefer, 2014; Macdonald, 1999; Smith \& Ingersoll, 2004). We explore the extent to which Quality Teaching Rounds address common factors related to attrition and thus have potential to not only retain more teachers, but develop their confidence, enhance the quality of their teaching, and build their capacity to continually learn.

In our view, developing pedagogical skill and expertise is often neglected in the induction phase of teachers' careers, in favour of broader orientations to school and teaching and diverse forms of socialemotional support (Gore, Williams, \& Ladwig, 2007; Williams, Gore, \& Cooper, 2004). For example, a recently published national survey of teachers in Australian schools asked beginning teachers about the forms of assistance they had received since they began teaching and how helpful each had been (McKenzie, Weldon, Rowley, Murphy, \& McMillan, 2014). Seven options were provided: a designated mentor, an orientation program designed for new teachers, observation of experienced teachers teaching their classes, structured opportunities to discuss experiences with other new teachers, a

\footnotetext{
${ }^{1}$ Thomas del Prete did write about rounds in 1997, in what appears to be an internal or local newsletter.
} 
reduced face-to-face teaching workload, follow-up from the teacher education institution, and other assistance. Of these, both primary and secondary teachers reported that mentors and orientation programs were the most commonly provided forms of support while observation of experienced teachers was the most helpful (McKenzie et al., 2014). Other studies have also reported that beginning teachers value opportunities to work collaboratively with colleagues but such opportunities are rare (Alkins, Banks-Santilli, Elliot, Guttenberg, \& Kamii, 2006; Andrews, Gilbert, \& Martin, 2007). Our focus on supporting beginning teachers through Quality Teaching Rounds not only provides them with opportunities to observe other teachers, but also to engage in sustained, focused, critical conversations about each other's practice.

Our analysis demonstrates the strong potential of Quality Teaching Rounds for shaping the successful transition from preservice to inservice teaching. We argue that the pedagogical framework and specific processes of our approach to rounds are critical to ensuring its positive effects for beginning teachers.

\section{Quality Teaching Rounds}

\subsection{Overview}

Quality Teaching Rounds (hereafter referred to as QT Rounds) as we have developed the approach in Australia, involves teachers, at any point in their careers, working in professional learning communities (PLCs), typically in groups of four to eight. A "round" is comprised of three sequential sessions that occur on a single day:

1. discussion of a professional reading, chosen by a PLC member, which is designed to support the group in developing a shared basis for their professional conversations, learning more about each other's beliefs and values as they pertain to teaching and learning, and exploring implications of policy and school initiatives for their practice (typically one hour);

2. classroom observation, in which one PLC member teaches a lesson that is observed by all other members of the PLC (a full lesson length, typically 40-80 minutes); and

3. individual coding (usually 30 minutes) followed by group discussion of the lesson by all PLC members, including the teacher (typically one to two hours), using the Quality Teaching pedagogical framework (see below).

Every PLC member takes their turn to teach an observed lesson. In each round teachers are encouraged to reflect not only on that lesson, but how it relates to their own practice and to teaching at their school in general. The members of each PLC, usually volunteers within their school, negotiate norms for their group in relation to such matters as confidentiality, note-taking during lessons, and interacting with students during observations. These negotiations are considered important if teachers are to feel more rather than less comfortable in the deprivatisation of practice. They are intended to help build trust and counter a well-documented reluctance of teachers to open up classrooms for peer observation (Elmore, 2002; Little, 1990) and/or adopt a level of politeness that avoids critical analysis of their practice (Hargreaves, 1994).

QT Rounds differ from many other forms of rounds in a number of ways as summarized in Table 1. In QT Rounds, at least one lesson is observed for every member of the PLC, and PLC members stay together for an entire set of rounds (typically meeting once every week or two). The teacher who taught is a full participant in the coding and discussion after the lesson which, guided by the Quality Teaching framework (see below), addresses many aspects of the lesson. Some members of each PLC 
participate in a two-day training session to prepare for undertaking QT Rounds and help facilitate the process, however the intent is to position all PLC members as learners, to flatten the power hierarchy, and to avoid the adoption of a mentor/coach/expert role by any individual. The coding instrument and process of taking turns to share codes, evidence and insights with other members of the PLC in relation to each element of the framework before attempting to reach agreement as a group for that element provides both structure and substance for teachers' conversations. The intent of QT Rounds is to focus on the relationship between classroom practice and student learning and to show respect for the teacher and the teaching-learning process by watching a whole lesson each time.

\section{Table 1}

Distinguishing features of Quality Teaching Rounds

\begin{tabular}{ll}
\hline \multicolumn{1}{c}{ Other rounds } & \multicolumn{1}{c}{ Quality Teaching Rounds } \\
\hline $\begin{array}{l}\text { Observing others } \\
\text { Walkthroughs, short observations }\end{array}$ & Observing each other \\
$\begin{array}{l}\text { Focus on one or a small number of lesson } \\
\text { aspects }\end{array}$ & Full lesson observations \\
May involve lesson teacher in discussion & Focus on comprehensive set of lesson aspects \\
Group membership may change & $\begin{array}{l}\text { Must involve lesson teacher in discussion } \\
\text { Consistent membership throughout a full set of } \\
\text { rounds }\end{array}$ \\
Observation and analysis based on current & $\begin{array}{l}\text { Observation and analysis shaped by QT } \\
\text { framework }\end{array}$ \\
Confidentiality may be expected & Confidentiality maintained by group members \\
Involves mentoring/coaching/expert & Flattens power hierarchy \\
May focus on whole school/jurisdiction & $\begin{array}{l}\text { Focuses on classroom practice and student } \\
\text { learning }\end{array}$ \\
\hline
\end{tabular}

\subsection{A pedagogical framework}

Fundamental to QT Rounds is the structuring of observations and post-lesson discussions by the Quality Teaching framework (hereafter referred to as the QT framework) (NSW Department of Education and Training [NSWDET], 2003). This pedagogical framework has been extensively used during the past decade in Australia (particularly in New South Wales and the Australian Capital Territory). It was derived from Newmann and Associates' (1996) work on Authentic Pedagogy and an extensive synthesis of research on aspects of pedagogical practice that make a difference for student outcomes (Ladwig \& King, 2003). Grounded in analysis by teachers and researchers of hundreds of lessons (Ladwig, 2007, 2010), the framework offers a comprehensive account of teaching, addressing matters of curriculum, student engagement, and social justice, as well as pedagogical practice, in shaping student learning (Gore, 2007).

The framework focuses teachers' attention on three dimensions of pedagogy, "Intellectual Quality", "Quality Learning Environment", and "Significance", each consisting of six elements as depicted in 
Table 2. Where teaching quality, defined in this way, is occurring, student achievement improves measurably (Gore, 2014; Ladwig, 2007) and equity gaps narrow, especially enduring gaps between students from high and low SES backgrounds and between Aboriginal and non-Aboriginal students (Ladwig, Gore, Miller, Griffiths, \& Smith, 2007).

\section{Table 2}

Elements of the Quality Teaching framework

\begin{tabular}{lll}
\hline Intellectual Quality & Quality Learning Environment & Significance \\
\hline Deep knowledge & Explicit quality criteria & Background knowledge \\
Deep understanding & Engagement & Cultural knowledge \\
Problematic knowledge & High expectations & Knowledge integration \\
Higher-order thinking & Social support & Inclusivity \\
Metalanguage & Students' self-regulation & Connectedness \\
Substantive communication & Student direction & Narrative \\
\hline
\end{tabular}

Each element is framed as an inquiry question to focus teachers' observations and discussions rather than as a rigid directive about what every lesson or every classroom must look like. For example, in relation to the element of Deep Knowledge, teachers ask, "To what extent does the knowledge addressed in the lesson focus on a small number of key concepts and the relationships between them?" In relation to the element of Explicit Quality Criteria, teachers ask, "To what extent are students provided with clear criteria for the quality of work they are to produce?" And in relation to Cultural Knowledge, they consider, "To what extent does the lesson incorporate the cultural knowledge of diverse social groupings?" These kinds of questions enable teachers to discuss not only what they see in a lesson but also what they believe and value about good teaching. The investigation of these issues is made more rigorous through the shared experience of the lesson and the level of detail addressed in the coding and discussion processes.

The QT framework provides teachers with concepts, the associated language, and fine-grained indicators of quality (using a 1-5 scale) to help them describe and analyse local classroom-based evidence. Coding lessons is central to this approach (for a more detailed discussion see Bowe \& Gore, under review). Teachers individually code lessons, using the 18 elements of the framework, ideally soon after the lesson is over. Next, they take turns to articulate their thinking to one another about how they reached a particular code-what they observed in the lesson, what evidence they drew on to make their determination, how they understand or interpret a particular element or descriptor. After every teacher has shared their views, the group attempts to reach agreement about the best code for that element in that lesson, before moving to the next element. The point is not to quickly agree on a code but to interrogate their assumptions, to carefully consider outliers and alternate views, and to explore what it might take to achieve a higher code in that activity. These discussions typically take between one and two hours and foster collective analysis, judgment, and debate. 


\section{Researching Quality Teaching Rounds}

Quality Teaching Rounds were first trialed in 2008 and subsequently implemented in 2009 as part of a project funded by the Australian Research Council. They have since been conducted in more than 50 schools in three different education jurisdictions in Australia. Our studies of QT Rounds have taken three forms: (1) a preliminary investigation of the viability and impact of QT Rounds, sustained over three years; (2) "design experiments" (Penuel, Fishman, Cheng, \& Sabelli, 2011)2, in which schools deliberately manipulated their approach to QT Rounds in order to test their adaptability to local circumstances and fewer resources; and (3) a cluster randomised controlled trial, currently in progress, which builds on our prior theoretical and empirical work to test different forms of QT Rounds under robust CONSORT guidelines (Campbell, Elbourne, \& Altman, 2004) and also uses interview data to explore not only what works but how, why, and for whom (see Appendix 1 for more detail on each study) (Gore, 2014). Data for this paper were drawn from all three studies.

\subsection{Sample and data}

Our analysis for this paper draws on face-to-face interviews with 39 early career teachers who participated in QT Rounds within one of the three studies outlined above ${ }^{3}$. Of these teachers, there were 32 females and 7 males, 22 in primary schools and 17 in secondary schools. Interviews typically lasted for 30 to 40 minutes. Participants were asked to compare aspects of their experience before and after participating in QT Rounds. Specifically we asked: Compared to when you began teaching, how (if at all) has your participation in QT Rounds changed:

- What you think about?

- What you talk about?

- What you do as a teacher?

- How you feel about teaching as a profession?

- How you view and interact with your colleagues?

- How you view and interact with your students?

- How you see yourself as a teacher?

- Your plans for your career? ${ }^{4}$

To signal the particular QT Rounds experience of teachers cited in our analysis we have labelled interview excerpts with the teacher's name (pseudonym), study $(1,2$, or 3$)$, sector (primary or secondary), and year of teaching experience at time of interview (first to third). While these indicators convey detail about teachers' experience of QT Rounds and may be of interest to readers, there were no apparent differences among the studies in the reported effects on participating teachers. Hence the interview data from all three studies were consolidated for the analysis.

\footnotetext{
${ }^{2}$ Design research in education involves engineering particular forms of learning in a natural environment, such as teacher professional learning communities, and systematically studying how that learning takes place in iterative cycles (Cobb, Confrey, diSessa, Lehrer, \& Schauble, 2003; Penuel, Fishman, Cheng, \& Sabelli, 2011).

${ }^{3}$ While all teachers participated voluntarily in the research, it should be noted that there were several instances when they were "encouraged" by a principal or colleague rather than enthusiasts for this kind of collaborative professional development. The sample is therefore reasonably representative of early career teachers and not a highly selective sample. In each study, it was left to the schools to identify and select teachers willing to participate in QT Rounds.

${ }^{4}$ These are the specific questions asked in the third study. In the first two studies, the questions were less direct and are provided as Appendix 2.
} 


\subsection{Data analysis}

To identify the underlying mechanisms (Lewis, Perry, \& Murata, 2006) that enable QT Rounds to work, we use an analytic framework designed to explore the: (1) "discursive" (what is discussed and what is not discussed; (2) "subjectification" (how teachers are thought about and how they think about themselves); and (3) "lived" (the impact on lives) effects (Bacchi, 2009, 2010) of QT Rounds. Following Bacchi (2010), we argue that this kind of analysis can open up rounds as a policy (as taken up by departments of education) and as a social science theory (as discussed throughout this special issue) to critical scrutiny, probing its "grounding assumptions" (p. 7). That is, if rounds provide a solution, then how they are conceptualised, how they are represented, matters in terms of their effects. Different approaches to rounds will provide competing representations of "the problem" (with teachers, teaching, and/or teacher education) with implications for how they/we are governed (Foucault, 1991; St. Pierre, 2006).

This analysis of the effects of rounds stems from the notion that what we do and how we see ourselves as teachers is constituted by the discourses and power relations within which we are located, both as individuals and as a profession. The discourses we invoke in planning for and talking about teaching, or discussing what is good teaching, will shape and be shaped by our practice and how we understand ourselves as teachers. For example, if our primary conception of good teaching is a quiet and orderly classroom, then we are likely to define ourselves as successful teachers based on the behavior and responsiveness of our students and treat classroom management as a precursor to productive learning (Gore \& Parkes, 2008). The point of this kind of analysis is to reflect on how specific practices, such as rounds, affect our lives and to reflect on where these practices come from.

Verbatim interview transcriptions were read by at least two members of our research team and coded for themes relating to the three effects. What teachers said they were thinking and talking about, what discourses they were drawing on in the context of participating in QT Rounds, were explored as discursive effects. How teachers, as subjects, thought and talked about their colleagues and themselves, and how they positioned themselves to be certain kinds of teachers, were explored as subjectification effects. Any specific impacts they reported on their lives and how their participation in QT Rounds was manifest in the classroom and/or the staffroom were explored as lived effects.

Our aim here is to explore at a deep level the specific aspects of QT Rounds that shaped the experiences of these 39 beginning teachers. In the final section of the paper, we consider the question of what the problem is represented to be when QT Rounds are the proposed solution (Bacchi, 2010).

\subsection{The effects of Quality Teaching Rounds}

What beginning teachers talk and think about will invariably shape and be shaped by how they are seen by others and how they see themselves, and what they do and experience in their work in schools. Clearly the three types of effects of QT Rounds (discursive, subjectification, and lived) are interrelated. They are separated out here for analytical purposes. The teacher comments we present are representative of their views. Although we searched for disconfirming evidence and negative responses, the participating teachers universally talked about QT Rounds in positive terms. Given space restrictions we have limited ourselves to one or two quotes to illustrate each point when there were many we could have chosen. 


\subsubsection{Discursive effects}

Participation in QT Rounds reportedly had a profound impact on how teachers conceptualise and talk about teaching. Many spoke of how the QT framework "gave" them knowledge or "structure" for thinking about teaching:

"It makes you aware of how you're going to deliver your teaching ... QT gives you that extra knowledge that you're always mindful of; it's like you've got a little pocket in the back of your mind and you know that you have to do this and that." (Rose, study 1, primary, first year)

"It's a bit of structure and I'm the kind of person who really likes structure. I like to ... have clear goals and, you know, learning intentions and it sort of gives you something-it's kind of like a quality check almost." (Ayesha, study 3, secondary, third year)

These teachers speak with clarity about the direction the framework offered. It "gave" them "extra knowledge," a "bit of structure," "something" they didn't already have to help shape their planning and practice. They could draw on the body of knowledge gained from their recent teacher education programs and the broad guidelines provided by the Australian Professional Standards for Teachers (Australian Institute for Teaching and School Leadership, 2011). But it seems the QT framework provides a different kind of structure to guide their thinking, their understanding of teaching, in ways they found helpful. It helped them to "know" what they wanted to achieve.

One teacher discusses how she refined her approach to questioning in ways that would better support students' construction of knowledge:

"The way that I ask questions, and the way that I facilitate discussions [have changed]. I [now] try and get [students] to be thinking more high[er] order, [using] more problematic knowledge, trying to get them to question each other and to question ... norms and what society believes, and [ask] 'should we just accept that?' So I'm really trying to facilitate a discussion which is richer rather than 'yes/no' questioning. I've definitely changed the way I question the students and facilitate discussions." (Emma, study 3, secondary, first year)

Emma's language invokes elements of the framework: "higher-order thinking", "problematic knowledge." These concepts appear to help Emma articulate and aim for better quality class discussions and substantive communication. The representation of good teaching provided by the QT framework helps her to seek richer discussions with her students.

Another teacher explains how the elements shape planning and ongoing reflection on teaching:

"When I'm in a lesson or I'm planning, I think about [Quality Teaching] because [I've had] so much exposure to the elements ... I just think about them all the time when I'm planning, so it has an impact on my lessons. ... I think ... 'that was excellent metalanguage' or those kinds of things. You're self-evaluating as you go. And I'll make sure I bring in the cultural knowledge [element] and getting more background knowledge from the children, making sure that we're ... building from there, [from] what they know." (Amy, study 1 , primary, third year)

Amy's use of the elements "metalanguage", "cultural knowledge", and "background knowledge", illustrates how teachers were enabled to talk about practice. They draw on the QT framework as a form of specialised language, offering them a kind of shorthand for talking with colleagues about key concepts of practice. Many studies have found teachers are constrained in their capacity to 
communicate with colleagues by a relative lack of shared concepts and language (Berliner, 1987; Elmore, 2007). This communication barrier is likely to be more keenly felt by beginning teachers and contribute to feelings of isolation as they attempt to make sense of and fit in to new school cultures.

As well as providing beginning teachers with a powerful tool for strengthening communication, the QT framework also helped them grasp the "big picture" of teaching and clarify the outcomes they wanted to achieve:

"So when I started it was just getting through the lesson, just trying to get the kids to know the knowledge. That was it. If I could come back and ask them a question and they could regurgitate it, fabulous me. Now it's actually making it really contextualised, really relevant, getting the kids to expand upon what we've learnt, just building that confidence. I definitely know l'm doing this and the kids are more engaged." (Bree, study 3, primary, first year)

Instead of being satisfied with "regurgitated" answers, Bree and her peers clearly and quickly focused on the quality of their students' learning. These statements counter Fuller and Bown's (1975) widelycited "developmental" account of learning to teach through three stages of concerns: concerns about self; concerns about tasks/situations; concerns about impact on students. Participating in QT Rounds accelerated a focus on impact and the teaching practices that would produce good learning outcomes.

Importantly, the teachers also highlighted the openness and adaptability of QT, not as a doctrine to be applied unquestioningly, or about trying to achieve perfect scores, but rather as supporting the ongoing process of learning to teach:

"Some lessons I still—I'll just do what I was doing before, but it's made me think about ways of incorporating [Quality Teaching]. Like every lesson I think about, 'Oh yeah, you could do that there', and then I'll put a little note next to it for next time I teach it and things. You're just slowly adding in little bits here and there. ... [It's not] whether we're doing the right thing or wrong thing. It's more about how can I get the kids to achieve better results, what can I change and modify within my own practice, and what do I need to focus on a bit more that I've perhaps neglected in the past." (Melissa, study 3, secondary, third year)

We argue that two key mechanisms produced these discursive effects: the comprehensiveness and specificity of the QT framework itself and the conversations it enabled. Reverberating throughout the interviews are the ways in which both the overall coherence of the framework and the detail associated with each element explicitly shaped teacher awareness. Quality Teaching established a "common language" to support the discussions among teachers, providing tools for analysis, a way of getting distance on practice, and enabling them to see clearly what they wanted to achieve.

"I think this has definitely been ... the best professional learning l've had at the school ... just the way in which all the staff are using a common language. When we're talking about Quality Teaching, you know, we've got that common language. Everyone kind of knows what it's about now, so you can ... talk about the lessons and people know what you're saying." (John, study 1 , secondary, second year)

"I think that's what's made it most powerful, is ... having the conversations about what makes good teaching.... Knowing that we could see these elements in the teacher's practice, find them, share them, discuss them, disagree ... knowing that [when] we said higher-order thinking we all knew what that meant." (Jacinta, study 1, primary, third year) 
Having a common set of concepts and language for discussing the quality of teaching appears to be critical to the quality of professional conversations and depth of analysis produced through QT Rounds. The concepts and language beginning teachers acquire through teacher education programs are often overwhelming, lacking in overall coherence or structure (Grossman, Hammerness, McDonald, \& Ronfeldt, 2008) and not shared among teachers from different programs. The statements that constitute the teaching standards operate at a different level of specificity and require substantial professional judgment. They tend to be relatively ambiguous, using terms like "effective strategies" rather than specifying what effective means, or what constitutes good teaching (Ladwig \& Gore, 2009). As City, Elmore, Fiarman, and Teitel (2009) argue, "one of the greatest barriers to school improvement is the lack of an agreed-upon definition of what quality instruction looks like" (p. 3). The QT framework, by contrast, articulates a vision of good teaching and provides a shared discourse for professional conversations about teaching and learning.

\subsubsection{Subjectification effects}

For many teachers, participation in QT Rounds was pivotal to a transition from feeling like survivors in the classroom to seeing themselves as teachers:

"Well at the beginning it was just survival, you know, I just wanted to make it from 9 to 3 . And now ... I think, well what are the kids getting from it? I really think ... what did they learn? So ... QT Rounds have helped in that regard." (Dean, study 3, primary, first year)

"I feel that I'm doing quality teaching now rather than, yes, just kind of going along with the flow. I think it gives you a bit of a [kick]start—like, [realising] 'I'm not really doing what I set out to do'. Yes, so it kind of wakes you up and makes you re-evaluate what you're doing which I think's really good." (Wendy, study 2, primary, second year)

These statements capture the potential of QT Rounds for helping beginning teachers become the kind of teachers they set out to be. QT Rounds also provided affirmation that they were "on the right track":

"[l'm] feeling comfortable in myself in my teaching, because I find, like, there's a lot of selfdoubt when you first come out. So you're just, like, 'Am I doing this right? Am I not?' ... But going through this process I've just got a lot more confidence in my abilities and I've found that I don't sit at home going, 'Oh, have I done that right, or would this child be any better if I did this instead?' It's kind of like, 'No, you're doing a good job so let's focus more on the curriculum and less on the self-reflection and doubt."' (Felicity, study 3, secondary, second year)

However, the experience of QT Rounds not only impacted on how teachers saw themselves. It facilitated the taking up of a different subject position in relation to their colleagues. New teachers often feel, or are made to feel, their relative inexperience. With QT Rounds, they became colleagues, borne of a new confidence created by the levelling effects of engaging in collaborative analysis of each other's practice:

"I see myself as a colleague ... not on the same level but I can interact on the same level. It's not like, 'Okay, they've got $x$ amount of years of experience, who am I to provide input?' It kind of makes me feel like we're on a level playing field again, the same." (Bree, study 3, primary, first year) 
"I think I'm ... more willing to interact with them-I don't feel as intimidated. As a new teacher you sort of sit back and go, 'I don't really know what they're talking about' but QT has given me a lot more confidence so I know I can speak a bit more because I'm more confident as a teacher. I'm not afraid to speak in front of people, even if I'm wrong. (Kate, study 3, secondary, second year)

Both Bree and Kate convey the kind of "us/them" dichotomy that typically keeps beginning teachers in their place. QT Rounds fostered a greater sense of agency, a capacity to express opinions, to be a player rather than an observer, afraid to speak, wondering "who am I" to participate. It also encouraged them to see their colleagues as still learning and questioning how best to teach:

"Even the more experienced teachers who have been doing QT [Rounds] are really taking it on board as well and they're asking a lot of questions which shows ... that you could be teaching for 20 plus years and still have a lot of questions." (Derek, study 1, primary, third year)

"As an early career teacher there's a lot of other very experienced teachers, and ... you don't see anybody teach usually. So ... you think, 'Gosh, they know everything about teaching and I don't know anything' or whatever. I think it felt like it did put us all more on a bit of a level playing field. ... I ... now view myself as, 'Gosh, okay, well maybe I'm not as terrible as I thought'—you know, 'these other people are doing this and I do that [too], that's great. Okay, obviously I'mthat must be okay' or what have you. It made me see them, I guess, as a bit more vulnerable." (Victoria, study 3, primary, second year)

Rather than feeling inferior, associating their own lack of experience with a lack of clarity about what to do or with relatively poor performance, QT Rounds provided an opportunity to see their colleagues in new ways.

These subjectification effects-moving from survivor to teacher, with greater confidence and a growing sense of being a colleague, of belonging - have much to do with the way the QT framework fostered a shared vision of good teaching. The language and concepts of the framework, as well as its manageable structure was able to be internalised, readily articulated and shared among teachers.

But it is not just the framework that matters. We argue that the processes that are fundamental to the conduct of QT Rounds are also critical mechanisms in the production of these effects. First, the small number of teachers in a PLC adds to the level of comfort experienced by beginning teachers:

"One thing that I've really liked about this is that there's just been the four of us, so you're almost-not forced, but you have to speak up. You do get the opportunity to share your thoughts and to speak. I know when we were coding, you know, we'd have to justify why we gave ... that particular code. ... That's been the best thing about this is that it's been in a small [group]. I've gotten to really know three other teachers and their practices throughout this time. I feel like I've been heard." (Victoria, study 3, primary, second year)

Second, with all PLC members taking their turn to host lesson observations, QT Rounds provide a very different process than coaching or mentoring. QT Rounds flatten rather than depend upon hierarchical power relations.

Third, the turn-taking that is part of the post-observation discussions is fundamental to keeping all teachers, no matter their level of experience, included as active participants in those conversations. This inclusion is critical to teachers early in their careers developing a sense of belonging and the kinds 
of relationships with colleagues that can sustain and support them. Jacinta explains how the process of QT Rounds assisted her to remain "a part" of everything:

"One instance I think ... [my] score was something completely way off what everyone else had coded and I was like, 'Oh gosh, I was doing so well.' ... But I think what was more valuable was the talk around it and different people's insights into why they coded a particular way, so yeah, while it was just that one fleeting moment of, 'Oh dear, I'll just sink into my shell', the conversation allowed me to come back out I guess and then still be a part of all the conversations that came after, still be part of all the sessions that came after." (Jacinta, study 1 , primary, first year)

The systematic use of the QT framework in the process of conducting rounds enabled teachers to speak, helped them realise that they had a right to speak, be heard, contribute. These are powerful interruptions to discourses that position beginning teachers as naïve, unformed, as having a deficit (Schaefer, Long, \& Clandinin, 2012) and needing help in a unidirectional way.

\subsubsection{Lived effects}

The most commonly reported lived effect on the beginning teachers was the way QT Rounds fostered relationships with teachers with whom they otherwise might not have connected. Rounds helped newcomers feel less alone. Indeed the language used by teachers when talking about this issue was particularly evocative of a shift from terrible isolation to authentic connection:

"You get to know people that you don't really get to interact with because being in my little cage I don't really get to interact with ... the other teachers." (Bree, study 3, primary, first year)

"You're not feeling so insular. Some schools you go into you're very insular. You're in your own classroom. You're in your own world. Nobody comes in. Nobody checks what you're doing. You've got nobody to kind of validate that what you're doing is right, is wrong, could be done better, or that you are doing something fantastic, 'Let's share it with somebody else.'" (Karen, study 3, primary, third year)

Terms such as "cages", "insular" and "nobody" speak of powerful constraints on these early career teachers and intense feelings of isolation. With little interaction or sense of their capacities, it is little wonder that many early career teachers struggle to feel the level of satisfaction with the job that keeps them in teaching.

Teachers also used strong language to talk about the new professional relationships they established. Emma says she "never" spoke to anyone outside of her mathematics faculty, but now has a range of connections with her QT Rounds colleagues:

"Well before QT Rounds I never spoke to anyone really, outside of the maths staffroom. So it's been really good, like talking with Teacher $W$, she's really helpful, really practical, got some really good practical ideas and things, so it's been really good with her. And Teacher $X$ is really helpful with the discipline side of things and stuff, so it's really good talking to him. And Teacher $Y$... and Teacher $\mathrm{Z}$, I always speak to her a lot now about it, watching her lessons and things, because I love her lessons. She gives me a lot of good ideas and stuff, so it's been good." (Emma, study 3 , secondary, first year) 
Importantly, this liberation from isolation went well beyond simply having someone to talk to. The teachers consistently reported that they felt more comfortable asking for help, because of the strong professional bonds they formed with their colleagues:

"I've learnt that I need to reflect a lot more on my teaching and I've learnt that it's okay to ask for help and that you need to be open to feedback and not take it personally." (Grace, study 3 , secondary, second year)

"Like I said you've got all this communication all of a sudden and you form really good relationships and bonds with your peers, your colleagues, that now you can just ask for assistance ... where I wouldn't have broached that subject prior." (Bree, study 3, primary, first year)

Another lived effect was evident in how teachers spoke of working differently with their students, hence impacting on their students' lives. In particular, they talked of setting higher expectations for learning and seeing their students' capabilities:

"I feel like I've got higher expectations now because I'm seeing what they're capable of. So my expectations ... have risen because I think, 'Well, they can do this, so I need to expect more of them' and obviously when you have higher expectations the kids meet it, like they know if you have high expectations they've got to strive to get there and I think if you do it in a positive way too and you're encouraging the whole way through the process, they will try ... to meet your high expectations." (Grace, study 3, secondary, second year)

For many early career teachers, participation in QT Rounds also cemented their desire to teach, to remain in teaching, with a stronger sense of control:

"[Before Rounds] it was so overwhelming, so isolating that I actually didn't know if the four years [of university] was worth it. After doing all of this I'm like, 'Oh, I can actually get there'. I love what I do." (Bree, study 3, primary, first year)

"I can see why ... early career teachers do burn out, because they come in with this passion, this desire, they learn all this great stuff at Uni and how it should really work and they're confronted with reality. It's sort of like two worlds ... I've realised there's so much that I still have to learn as a result of doing this. [But] there's so much that I have control over as well, within my classroom, that will benefit the students." (Yasmin, study 3, secondary, first year)

We argue that one of the key mechanisms contributing to these lived effects was that teachers did not feel judged in QT Rounds. Instead the process was seen as creating a safe environment in which critical feedback could be provided:

"We couldn't have had the conversations we had ... with each other as teachers, about our practice, without it being safe. I don't think we could have openly critiqued each other's practice if we didn't feel safe." (Jacinta, study 1, primary, third year)

"When we started I never felt uncomfortable. I felt like I could say what I wanted without being judged or sort of looked down upon or anything like that. Everyone participated, I think, to the best of their ability. Because we all gave a conscious effort and we all tried to input as much as 
we could, it was like a warm friendly environment to me ... once a week. We had the shared goal, the shared vision that we wanted to learn from this; we wanted to improve. I think that helped us to create that environment where we felt comfortable enough with one another to shareto share our thoughts." (Karen, study 3, primary, third year)

These "safe" and "warm" conditions whilst learning together through analyzing each other's teaching, guided by the concepts and processes of the QT framework, produced genuine relationships of collaboration in the name of improved practice and improved student learning. Beginning teachers also felt that they were learning:

"Amazing, I've learnt so much about it and I know it's not about-you're not being judged on your lesson, I know you're not being judged as a teacher, but as a teacher I've learnt from other teachers definitely. Just the way that they deliver the lessons, the way that they conduct the lesson, and I've learnt so much. ... So yeah, you definitely get to learn other things, collaborate with other people, learn the elements ... they're in the back of your head now ... I can now reflect on myself a lot better than before ... reflect on [my] lessons." (Kate, study 3, secondary, second year)

"[QT Rounds] just continually challenges my teaching practice. So even being part of the process for three years, I still go, 'Oh, I still learn something new.'" (Jacinta, study 1, primary, third year)

Learning is the ultimate and often elusive goal of teacher professional development. As Hargreaves and Fullan (2012) argue, "professional expertise is not just having and being aware of evidence, it's also about knowing how to judge the evidence and knowing what to do with it" (p. 54). The reported learning of these teachers, together with the formation of strong professional relationships that can support ongoing learning, suggests the powerful potential of QT Rounds. Such effects on the lives of early career teachers might actually contribute to a reduction in attrition.

\section{Conclusion}

This analysis highlights features of QT Rounds that distinguish it from other approaches to rounds and indeed, from many other approaches to teacher development (Bowe \& Gore, under review). We have demonstrated that both the substantive focus of QT Rounds and the way in which they are conducted-their underlying mechanisms-contributed to their productive effects (discursive, subjectification, and lived effects) in shaping a positive transition from preservice to inservice teaching. The QT framework provided concepts and language with which early career teachers could envisage, discuss and plan for good teaching. It provided a "structure," as one teacher put it, for organising their knowledge and guiding their learning.

QT Rounds also created an "integrated" professional culture, rather than a veteran-oriented or novice-oriented culture. In integrated cultures, whereby teachers at all career stages collaborate, beginning teachers are more likely to remain in teaching (Johnson \& Birkeland, 2003). Powerfully, QT Rounds not only create such a culture but they also position beginning teachers as knowledge holders, as contributing members of a group, and as individuals from whom other teachers can learn (Shaefer et al., 2012). Following Shaefer et al. (2012), we argue that such positioning is critical if teachers are to not only be retained but be sustained in teaching. 
Our analysis also clarifies that our form of rounds conceptualises "the problem" in teacher development as one of an inadequate knowledge base which contributes to feelings of insecurity, vulnerability, and a lack of confidence among teachers. Such feelings mitigate their growth and both their opportunity and their capacity to engage in collaborative critical analytical work. In effect, without greater guidance, we too often ask people in schools to do what they don't know how to do (Elmore, 2002).

Indeed, we argue that some collaborative approaches to teacher development have gone too far in the name of respecting teachers' knowledge and capacity to (collectively) solve their own problems or, in this case, to successfully induct their new colleagues. Leaving teachers to figure out, often from scratch, how best to teach and how best to support beginning teachers has the effect of absolving ourselves, as academics and educational leaders, of the responsibility to support teacher growth and learning. QT Rounds, by contrast, helped these early career teachers to feel confident, guided their improvement, and helped in the transition from seeing themselves as new teachers to becoming colleagues in a profession in which everyone is still learning.

Before QT Rounds many of the beginning teachers had no clear idea of whether they were teaching well or not. They knew they were new. They felt their colleagues "knew everything". Many were hesitant to speak up, to ask for help. They lacked confidence in their own knowledge of teaching. Such views characterise much of the literature on early career attrition. The processes of conducting QT rounds provided the new teachers with valuable feedback on their practice without feeling that it was an appraisal, while also empowering them to discuss the practice of their more experienced colleagues.

As a result, the early career teachers in our research reported that they developed greater confidence, and stronger and more professional relationships with a more diverse range of colleagues. They reported that QT Rounds helped them feel able to speak and contribute to the profession. They reported having clearer direction for their work and deeper commitments to delivering good teaching. In short, Quality Teaching Rounds supported beginning teachers in the development of their pedagogy and in their growth as teachers. Such is the type of work that might slow attrition and help to advance the profession of teaching. 


\section{Acknowledgements}

We wish to express our gratitude to the beginning teachers who participated in the studies reported here and the research assistants who contributed to the collection and preliminary analysis of the data used in this paper: Rosie Barron, Julie Caddy, Debbie Drew, Hywel Ellis, Skye Gibson, and Wendy Taggart. We also acknowledge the support of the following funding bodies: Australian Research Council [LP0990068] and Catholic Education Office, Diocese of Parramatta (Study 1); Australian Capital Territory Education and Training Directorate and the University of Newcastle (Study 2); New South Wales Department of Education and Communities (Study 3).

\section{References}

Alkins, K., Banks-Santilli, L., Elliott, P., Guttenberg, N., \& Kamii, M. (2006). Project QUEST: A journey of discovery with beginning teachers in urban schools. Equity and Excellence in Education, 39(1), 6580.

Andrews, S. P., Gilbert, L. S., \& Martin, E. P. (2007). The first years of teaching: Disparities in perceptions of support. Action in Teacher Education, 28(4), 4-13.

Australian Institute for Teaching and School Leadership (AITSL). (2011). Australian Professional Standards for Teachers. Retrieved from http://www.aitsl.edu.au/docs/default-source/apstresources/australian_professional_standard_for_teachers_final.pdf

Bacchi, C. (2009). Analysing policy: What's the problem represented to be? Frenchs Forest, Australia: Pearson Education.

Bacchi, C. (2010). Foucault, policy and rule: Challenging the problem-solving paradigm. Aalborg, Denmark: Institut for Historie, Internationale Studier og Samfundsforhold, Aalborg Universitet.

Berliner, D. C. (1987). Ways of thinking about students and classrooms by more and less experienced teachers. In J. Calderhead (Ed.), Exploring teachers' thinking (pp. 60-68). London, UK: Cassell.

Bowe, J. M., \& Gore, J. M. (under review). Reassembling teacher professional development: The case for Quality Teaching Rounds.

Bowe, J., Gore, J., \& Elsworth, W. (2010). Rounding out professional development: Professional learning community, instructional rounds and quality teaching. Paper presented at the annual conference of the Australian Association for Educational Research, Melbourne, Australia. Retrieved from AARE website: http://www.aare.edu.au/data/publications/2010/2445cBoweGoreElsworth.pdf

Campbell, M. K., Elbourne, D. R., \& Altman, D. G. (2004). CONSORT statement: Extension to cluster randomised trials. British Medical Journal, 328(7441), 702-708. http://dx.doi.org/10.1136/bmj.328.7441.702

City, E. A., Elmore, R. F., Fiarman, S. E., \& Teitel, L. (2009). Instructional rounds in education: A network approach to improving teaching and learning. Cambridge, MA: Harvard Education Press.

Cobb, P., Confrey, J., diSessa, A., Lehrer, R., \& Schauble, L. (2003). Design experiments in educational research. Educational Researcher, 32(1), 9-13.

Clandinin, D. J., Downey, C. A., \& Schaefer, L. (Eds.). (2014). Narrative conceptions of knowledge: Towards understanding teacher attrition. Bingley, UK: Emerald Group.

Del Prete, T. A. (1997). The rounds model of professional development. From the Inside, 1(1), 12-13.

Del Prete, T. A. (2013). Teacher rounds: A guide to collaborative learning in and from practice. Thousand Oaks, CA: Corwin.

Elmore, R. F. (2002). Bridging the gap between standards and achievement: The imperative for professional development in education. Washington, DC: Albert Shanker Institute. Retrieved from http://www.shankerinstitute.org/Downloads/Bridging_Gap.pdf

Elmore, R. F. (2007). Professional networks and school improvement. School Administrator, 64(4), 20 25. 
Foucault, M. (1991). The Foucault effect: Studies in governmentality (G. Burchell, C. Gordon, \& P. Miller, Eds.). Chicago, IL: University of Chicago Press.

Fuller, F. F., \& Bown, O. H. (1975). Becoming a teacher. In K. Ryan (Ed.), Teacher education (74th Yearbook of the National Society of Education, pp. 25-52). Chicago, IL: University of Chicago Press.

Gore, J. M. (2007). Improving pedagogy. In J. Butcher \& L. McDonald (Eds.), Making a difference: Challenges for teachers, teaching and teacher education (pp. 15-34). Rotterdam, Netherlands: Sense.

Gore, J. (2014). Effective implementation of pedagogical reform through Quality Teaching Rounds. In Proceedings of the annual national conference of the Australian College of Educators (ACE): What counts as quality in education? (pp. 16-21). Melbourne, Australia: ACE.

Gore, J. M., Bowe, J., Clement, J., Ellis, H., \& Miller, W. (2012). Garnering teacher commitment to pedagogical reform. Paper presented at the annual meeting of the American Educational Research Association, Vancouver, Canada. Retrieved from the AERA Online Repository: http://www.aera.net/Publications/OnlinePaperRepository/tabid/10250/Default.aspx

Gore, J. M., \& Parkes, R. J. (2008). On the (mis)treatment of management. In A. Phelan \& J. Sumsion (Eds.), Critical readings in teacher education: Provoking absences (pp. 45-60). Rotterdam, Netherlands: Sense.

Gore, J. M., Williams, C. A., \& Ladwig, J. G. (2007). On the place of pedagogy in the induction of early career teachers. Paper presented at the annual conference of the Australian Association for Research in Education, Adelaide, Australia. Retrieved from AARE website: http://www.aare.edu.au/data/publications/2006/gor06387.pdf

Grossman, P., Hammerness, K. M., McDonald, M., \& Ronfeldt, M. (2008). Constructing coherence structural predictors of perceptions of coherence in NYC teacher education programs. Journal of Teacher Education, 59(4), 273-287.

Hargreaves, A. (1994). Changing teachers, changing times: Teachers' work and culture in the postmodern age. London, UK: Cassell.

Hargreaves, A., \& Fullan, M. (2012). Professional capital: Transforming teaching in every school. New York, NY: Teachers College Press.

Hawley, W. D., \& Valli, L. (1999). The essentials of effective professional development: A new consensus. In L. Darling-Hammond \& G. Sykes (Eds.), Teaching as the learning profession: Handbook of policy and practice (pp. 127-150). San Francisco, CA: Jossey-Bass.

Imants, J., \& van Veen, K. (2010). Teacher learning as workplace learning. In E. Baker, B. McGaw, \& P. Peterson (Eds.), International encyclopedia of education (3rd ed., pp. 569-574). Oxford, UK: Elsevier.

Johnson, S. M., \& Birkeland, S. E. (2003). Pursuing a "sense of success": New teachers explain their career decisions. American Educational Research Journal, 40(3), 581-617. Retrieved from http://aer.sagepub.com/content/40/3/581.full.pdf

Ladwig, J. G. (2007). Modelling pedagogy in Australian school reform. Pedagogies: An International Journal, 2(2), 57-76.

Ladwig, J. G. (2010). Beyond academic outcomes. Review of Research in Education, 34, 113-141.

Ladwig, J. G., \& Gore, J. M. (2009). Re-reading the standards agenda: An Australian case study. In M. Simons, M. Olssen, \& M. A. Peters (Eds.), Re-reading education policies: A handbook studying the policy agenda of the 21st century (pp. 772-734). Rotterdam, Netherlands: Sense.

Ladwig, J. G., Gore, J. M., Miller, W. A., Griffiths, T. G., \& Smith, M. (2007). Quality of pedagogy and student achievement: Multi-level replication of authentic pedagogy. Paper presented the annual conference of the Australian Association for Educational Research, Fremantle, Australia. Retrieved from http://www.aare.edu.au/data/publications/2007/lad07283.pdf

Ladwig, J. G., \& King, M. B. (2003). Quality teaching in NSW public schools: An annotated bibliography. Sydney, Australia: NSW Department of Education and Training/Professional Support and Curriculum Directorate. 
Lewis, C., Perry, R., \& Murata, A. (2006). How should research contribute to instructional improvement? The case of lesson study. Educational Researcher, 35(3), 3-14. http://dx.doi.org/10.3102/0013189X035003003

Little, J. W. (1990). The persistence of privacy: Autonomy and initiative in teachers' professional relations. Teachers College Record, 91(4), 509-536.

Macdonald, D. (1999). Teacher attrition: A review of literature. Teaching and Teacher Education, 15(8), 835-848.

McKenzie, P., Weldon, P., Rowley, G., Murphy, M., \& McMillan, J. (2014). Staff in Australia's Schools (SiAS) 2013: Main report on the survey. Retrieved from Australian Council for Educational Research website: http://research.acer.edu.au/tll_misc/20/

Newmann, F. M., \& Associates. (1996). Authentic achievement: Restructuring schools for intellectual quality. San Francisco, CA: Jossey-Bass.

Newmann, F., King, B., \& Youngs, P. (2000). Professional development that addresses school capacity: Lessons from urban elementary schools. American Journal of Education, 108(4), 259-299.

NSW Department of Education and Training (NSWDET). (2003). Quality teaching in NSW public schools: A classroom practice guide. Sydney, Australia: NSW Department of Education and Training/Professional Support and Curriculum Directorate.

Penuel, W. R., Fishman, B. J., Cheng, B. H., \& Sabelli, N. (2011). Organizing research and development at the intersection of learning, implementation, and design. Educational Researcher, 40(7), 331337. http://dx.doi.org/10.3102/0013189X11421826

Roegman, R., \& Riehl, C. J. (2014). Playing doctor with teacher preparation. Paper presented at the annual meeting of the American Educational Research Association, Philadelphia, PA.

Schaefer, L., Long, J. S., \& Clandinin, D. J. (2012). Questioning the research on early career teacher attrition and retention. Alberta Journal of Educational Research, 58(1), 106-121.

Smith, T. M., \& Ingersoll, R. M. (2004). What are the effects of induction and mentoring on beginning teacher turnover? American Educational Research Journal, 41(3), 681-714.

St. Pierre, E. A. (2006). Scientifically based research in education: Epistemology and ethics. Adult Education Quarterly, 56(4), 239-266.

Williams, C. A., Gore, J. M., \& Cooper, S. A. (2004). The brave and the bold: Researching the professional lives of early career teachers. Imagine if... the impact of quality teaching on the socialisation of early career teachers. Paper presented at the annual conference of the Australian Association for Research in Education, Melbourne, Australia. Retrieved from AARE website: http://www.aare.edu.au/data/publications/2004/gor04696.pdf 


\section{Appendix 1. Overview of research on Quality Teaching Rounds}

\begin{tabular}{|c|c|c|c|}
\hline & Study 1 & Study 2 & Study 3 \\
\hline Project Title & $\begin{array}{l}\text { Effective implementation of } \\
\text { pedagogical reform } \\
\text { LP0990068 }\end{array}$ & $\begin{array}{l}\text { Investigating Quality } \\
\text { Teaching Rounds to } \\
\text { support teacher } \\
\text { professional learning }\end{array}$ & $\begin{array}{l}\text { Improving teaching } \\
\text { quality through peer } \\
\text { observation and } \\
\text { feedback: An } \\
\text { investigation of the } \\
\text { impact of Quality } \\
\text { Teaching Rounds }\end{array}$ \\
\hline Investigators & Gore, Amosa, Bowe & $\begin{array}{l}\text { Gore, Bowe, Mockler, } \\
\text { Smith }\end{array}$ & $\begin{array}{l}\text { Gore, Bowe, Smith, } \\
\text { Mockler, Lubans }\end{array}$ \\
\hline Funding body & $\begin{array}{l}\text { Australian Research Council } \\
\text { and } \\
\text { Catholic Education Office, } \\
\text { Diocese of Parramatta }\end{array}$ & $\begin{array}{l}\text { Australian Capital } \\
\text { Territory Education and } \\
\text { Training Directorate and } \\
\text { the University of } \\
\text { Newcastle }\end{array}$ & $\begin{array}{l}\text { New South Wales } \\
\text { Department of Education } \\
\text { and Communities }\end{array}$ \\
\hline \multicolumn{4}{|l|}{ Participants in study (no.) } \\
\hline Schools & 4 & 18 & 24 \\
\hline Teachers & 28 & 157 & 192 \\
\hline ECTS & 8 & 34 & 37 \\
\hline ECTs interviewed & 8 & 9 & 22 \\
\hline \multicolumn{4}{|c|}{ Varying features of Quality Teaching Rounds } \\
\hline Duration of intervention & 3 years & 2 school terms & 2 school terms \\
\hline Duration of each round & Full day & Few hours to full day & Half day to full day \\
\hline Participants per PLC & 8 & $3-8$ & $4-8$ \\
\hline PLCs per school & 1 & $1-6$ & $1-2$ \\
\hline Rounds taught per teacher & 3 & $1-2$ & $1-2$ \\
\hline External facilitator & First two years & No & No \\
\hline \multicolumn{4}{|c|}{ Common features of Quality Teaching Rounds } \\
\hline Reading discussion conducted & $\checkmark$ & $\checkmark$ & $\checkmark$ \\
\hline Every teacher hosts a round & $\checkmark$ & $\checkmark$ & $\checkmark$ \\
\hline $\begin{array}{l}\text { All PLC members attend } \\
\text { lesson observation }\end{array}$ & $\checkmark$ & $\checkmark$ & $\checkmark$ \\
\hline $\begin{array}{l}\text { All PLC members, including } \\
\text { host teacher, code the lesson } \\
\text { using QT Classroom Practice } \\
\text { Guide }\end{array}$ & $\checkmark$ & $\checkmark$ & $\checkmark$ \\
\hline $\begin{array}{l}\text { All PLC members, including } \\
\text { the host teacher, discuss the } \\
\text { lesson using evidence, codes } \\
\text { and QT framework }\end{array}$ & $\checkmark$ & $\checkmark$ & $\checkmark$ \\
\hline
\end{tabular}

Note ECT = early career teacher PLC = professional learning community. 


\section{Appendix 2. Interview questions, Study 1 and 2 (Study 3 questions provided in the text)}

1. General introduction:

1.1 What have been the highlights of your teaching this year?

1.2 What has been the main focus of Professional Development at the school in 2012?

1.3 To what extent is Professional Development being used at this school to support and develop teachers' use of QT?

1.4 Can you describe the best professional learning experience you've had and what made it so?

1.5 Can you describe a professional learning experience you've had that you felt was not valuable and what made it so?

2. Focusing on Quality Teaching Rounds (QT):

2.1 Please describe how QT Rounds were implemented in your school.

2.2 In your opinion, how is the implementation of QT Rounds progressing in [this system] and in your school in particular? How would you describe the general level of commitment to the initiative (can you quantify it)?

2.3 How would you describe the support for teachers attempting to use QT Rounds?

2.4 How would you describe the impact of QT Rounds on the school, your teaching and your students? What evidence can you point to that illustrates that impact? (Can you talk through an example or two about things you do differently or aspect of your teaching of which you are now more mindful?)

2.5 What is it about QT Rounds that is most powerful?

2.6 Based on your experience with the readings, and with QT Rounds, what, if anything, would you have changed about the way QT Rounds were implemented in your school?

2.7 Do you think QT Rounds have changed you as individuals and as a group? If so, how?

2.8 How well do you think your QT Rounds PLC has worked this year?

2.9 As a member of the PLC, can you comment on:

- The sense of community within the PLC

- What has helped build that sense of community

- What gets in the way of building/strengthening the community

- Your own experience in being part of the PLC community

2.10 What has been the most beneficial thing about being in QT Rounds? 